\title{
MODAL SOSIAL DALAM PENGINTEGRASIAN MASYARAKAT MULTIETNIS PADA MASYARAKAT DESA PAKRAMAN DI BALI
}

\author{
Gede Raga, I Wayan Mudana \\ Universitas Pendidikan Ganesha
}

\begin{abstract}
Abstrak
Penelitian ini bertujuan mengungkapkan tentang modal sosial dalam pengintegrasian masyarakat multietnis pada desa pakraman di Bali yang di dalamnya mencakup kemultietnikan masyarakat desa pakraman, pola pemukiman masyarakat multietnik, jaringan hubungan sosial antaretnis, bentuk-bentuk integrasi antar etnis, model kontrol sosial yang dikembangkan guna mempertahankan integrasi antaretnik pada desa pakraman.

Kajian terhadap hal itu akan dilakukan dengan memanfaatkan teori-teori kritis, dengan pendekatan kualitatif. Berdasarkan hal itu, terungkap bahwa masyarakat desa pakraman di Bali merupakan masyarakat multietnik, kemultietnikan tersebut dapat dilihat dari adanya berbagai kelompok etnik yang bermukim di wilayah tersebut, seperti etnis Bali, etnis Tionghoa, dan etnis Jawa. Pola pemukimannya pada umumnya cenderung mengelompok dan berada dekat dengan pusat aktivitas ekonomi, jalur utama dan cenderung berbaur dengan etnis lainnya. Jaringan hubungan sosial yang dikembangkan ada yang didasarkan atas kedekatan tempat tinggal, kekerabatan, kepentingan sosial, ekonomi, budaya dan politik. Integrasi sosialnya tampak dalam bentuk perkawinan, hubungan pertetanggaan/ hubungan tempat tinggal, persekutuan/perkumpulan/organisasi sosial baik yang berbasis sosial, budaya, ekonomi maupun politik. Model kontrol sosial yang dikembangkan berupa penanaman nilai melalui sosialisasi, pemanfaatan sistem sosial keluarga/kuren, desa pakraman, berbagai kelembagaan formal, dan dengan pemanfaatan budaya fisik seperti surat, telepon, radio, pengeras suara. Di samping itu, juga digunakan bahasa. Dengan kata lain kontrol sosial dalam pemeliharaan modal sosial dan integrasi antar etnik dilakukan secara sekala dan niskala.
\end{abstract}

Kata-kata kunci : modal sosial, integrasi, desa pakraman

\section{Abstract}

This study aims to understand on social capital in integration multiethnics community at Pakraman village community in Bali which includ about multiethnics of community in Pakraman village, settlement pattern of multiethnics community, net social relation among the ethnics, the shape of integration among ethnics, model of social control, that's developed for protecting the integration among ethnics at Pakraman village.

The analysis of the matters will be carried oun by using the critical theories, by qualitative approach. According to the matters, are known that the community of Pakraman village in Bali forms the multiethnic community, that multiethnic can be seen from some ethnic groups that exist in that area, such as Balinese ethnic, chinese ethnic, and Javanese ethnic. Their settlement pattern, is usually inclined to make a group and near the centre of economic activity. The main road inclined to socialized with the other ethnic. The net of social relation which is developed, there are based nearly the settlement, kinship, social importence, economy, culture, and politic. The shape of its social integrations are in marriage shape, neibour relation, ship/settlement relation, federation, association/social organization, that has a social bases, culture, economy, although politc. Model of social control is developed, such as value invesment through socialization, using family/clan social system, Pakraman village, the other of formal institution, and by using the physical culture, for example letter, telephone, radio, microphone, besides using langauage. By the other word social controle in taking care the social capital and intergration among the ethnics that's carried out in skala and niskala.

Key words; social capital, intergration, desa pakraman. 


\section{PENDAHULUAN}

Daerah Bali pada dasarnya merupakan suatu daerah yang bersifat terbuka. Keterbukaan Bali terhadap masyarakat lain, dapat dibuktikan dengan adanya berbagai peninggalan sejarah, baik dari zaman prasejarah maupun dari jaman sejarah (Soekmono, 1975; Kartodirjo, 1975 ; Ardika, 1989). Hubungan dengan dunia luar terus dimantapkan. Hal ini tampak dari semakin berkembangnya hubungan kebudayaan, perdagangan, dan politik dengan negara-negara lain (Agung, 1989; Kartodirdjo, 1975). Kehadiran berbagai kelompok etnis dalam masyarakat Bali tidak jarang diwarnai oleh penampakan ciri-ciri kultur etnisnya dan bersifat eklusif dalam satu perkampungan tertentu, seperti Kampung Cina, Kampung Jawa, Kampung Bugis, Kampung Arab, dan lain sebagainya. $\mathrm{Hal}$ itu dimaksudkan bukan saja dalam rangka memudahkan untuk mengenalinya, tetapi juga sebagai suatu strategi dalam mempertahankan identitas sosiokultural dan untuk menciptakan keamanan sosial. Kedatangan berbagai macam etnis ke Bali telah nampak sejak zaman kerajaankerajaan Hindu - Budha di Bali. Hal ini dapat disimak dari adanya berita-berita Cina yang menyebutkan tentang Bali dengan nama Poli (Muliana, 1981; Kartodirdjo, 1975). Keberadaannya terus berlanjut sejalan dengan dinamika sejarah masyarakat Bali. Hal ini dapat disimak dari adanya peninggalan-peninggalan berupa tinggalan budaya, tempat tinggal, tempat ibadah, adanya kelompok masyarakat etnik, dan lain sebagainya (Kartirdjo, 1975).

Mereka umumnya menetap dan memusat terutama di daerah pusat-pusat aktivitas ekonomi seperti pasar dan pelabuhan, sebagaimana dikemukakan oleh Koentjaraningrat (1982) yang menyatakan bahwa sejak beberapa abad lamanya kotakota pelabuhan kuno di Aceh, di Semenanjung Malaka, di daerah pantai Jawa Utara, dan banyak tempat lain di Indonesia telah mempunyai segolongan pedagang Tionghoa dan pedagang Arab. Di
Bali pada abad ke 19 Geertz menyatakan bahwa ada berbagai macam etnik yang memainkan peranan penting dalam aktivitas perdagangan pada kerajaan-kerajaan yang ada di Bali, sebagaimana nampak pada Kerajaan Klungkung, Kerajaan Badung, Kerajaan Buleleng, dan Tabanan. Kedekatannya dengan penguasa dan keberhasilannya dalam bidang ekonomi telah menempatkan dirinya sebagai orang terpandang di masyarakat, bahkan dengan tingkat kehidupan ekonominya telah menempatkan dirinya sebagai orang terpandang di masyarakat, bahkan kedudukannya menyamai kedudukan kaum bangsawan (2000). Kedatangan berbagai macam etnik di daerah lain telah memunculkan berbagai kepentingan dan masalah bagi masyarakat setempat.

Kenyataan tersebut juga tampak pada masyarakat Desa Pakrman di Bali, yang nampaknya sangat berbeda dengan fenomena yang terjadi di Bali. Hal ini terbukti dengan adanya hubungan yang harmonis dan terintegrasinya etnis-etnis dengan masyarakat desa pakraman setempat. Gejala seperti itu nampak pada masyarakat desa pakramanan di Bali seperti di Desa Pakraman Buleleng, Desa Pakraman Gelgel, Desa Pakraman Buda Keling, Desa Pakraman Dalung. Berdasarkan pengamatan sementara, dapat dinyatakan bahwa mereka hidup harmonis dengan masyarakat desa setempat. Hal ini dapat dilihat dari terjadinya perkawinan antaretnis Bali, terjadinya penyerapan budaya, terintegrasinya masyarakat multietnik dalam berbagai kelembagaan sosial keagamaan. Walaupun demikian bukan berarti mereka telah menghilangkan sepenuhnya identitas etnis. Hal ini dapat dilihat misalnya dengan adanya berbagai ritual yang berlatar belakang etnik. Tempat ibadah, tempat tinggal, bahasa, dan ritual social religious yang dilakoninya mencerminkan identitas etnis yang dimilikinya. Dalam rangka membentengi identitasnya, mereka juga membangun paguyuban-paguyuban yang berlabel etnis. 
Pentingnya kajian ini juga terkait dengan terbatasnya kajian tentang modal sosial dalam pengintegrasian masyarakat multietnik pada masyarakat desa pakraman di Bali. Oleh karena itu, dipandang perlu untuk melakukan kajian tentang "Modal Sosial dalam Pengintegrasian Masyarakat Multietnik pada Masyarakat Desa Pakraman di Bali (Sebuah Kajian Etnografi Kritis). Pentingnya kajian ini tidak saja terkait dengan ketertarikan penulisan pada masalah tersebut dan orisinalitas kajiannya tetapi juga terkait dengan permasalahan nasional yaitu masalah integrasi antaretnis, sebagaimana dikemukakan oleh berbagai pakar ilmu-ilmu sosial (Koentjaraningrat, 1982; Toker, 1997; Bachtiar, 1976). Arti penting penelitian ini semakin nampak jelas bila dikaitkan dengan semakin berkembangnya masalah sosial antaretnik yang terakumulasi dalam berbagai kerusuhan sosial, puncaknya tampak dengan terjadinya peristiwa kerusuhan pada pertengahan Mei 1998 (Tempo, 1991; Tempo, 1998; Tabloid Alternatif Bongkar, 1998; Laporan Pencari Fakta, 1998). Di pihak lain, pada masyarakat Bali tampak adanya hubungan yang harmonis dalam wacana "segilik seguluk sebayan taka" , menyama,dan "paras paros" antara etnis Tionghoa dengan warga desa pakraman di Bali sehingga melalui kajian ini akan dapat memberikan sumbangan dalam mengantisipasi masalah kerawanan sosial antaretnis, atau paling tidak kajian ini dapat dijadikan sebagai dasar pertimbangan dalam pengembangan model alternatif pembangunan kesatuan bangsa yang berwawasan budaya. Di samping itu, kajian ini akan dapat berkontribusi akademik bagi penguatan teori post modernisme/teori kritis, dan penggugatan terhadap teori modernis. Dengan kata lain, penelitian tentang hal ini tidak saja penting dilihat dari segi penambahan pembendaharaan pengetahuan sosial budaya (berfungsi akademis), tetapi juga dapat memberikan peluang bagi usaha untuk menanggulangi kekerasan antaretnik, disintegrasi antar anggota masyarakat (berfungsi praktis). Pemahaman latar belakang sosiokultural antaretnik dan perekat-perekat sosial budaya mungkin bisa digunakan sebagai pedoman untuk mengurangi kekerasan/ konflik yang terjadi. Hal semacam ini sangat diperlukan, mengingat bahwa seperti dikemukakan Galtung (1988) bahwa kehidupan manusia dewasa ini penuh dengan kekerasan, sehingga memerlukan upaya penanggulangan secara intensif dengan memakai pendekatan struktural maupun kultural. Dalam konteks itulah, kajian tentang modal sosial menarik untuk dicermati.

Konsep modal sosial pertama kali diperkenalkan oleh L.J. Hanifan pada awal abad ke-20. Hanifan menyatakan bahwa modal sosial bukanlah modal dalam arti biasa seperti harta kekayaan atau uang, tetapi lebih mengandung arti kiasan, tetapi merupakan asset atau modal nyata yang penting dalam hidup bermasyarakat. Di dalamnya terkandung kemauan baik, rasa bersahabat, saling simpati, serta hubungan sosial dan kerja sama yang erat antara individu dan keluarga yang membentuk suatu kelompok sosial (Atmadja, 2006; Mudana, 2010)

Selanjutnya, konsep tersebut dikembangkan oleh Piere Bourdieu, Robert Putman, James Colemen, dan Francis Fukuyama. Coleman (1988) mendefenisikan sebagai aspek-aspek dari struktur hubungan antarindividu yang memungkinkan mereka menciptakan nilai-nilai baru. Modal sosial tersebut mengacu pada aspek-aspek utama dari organisasi sosial, seperti kepercayaan, norma-norma, dan jaringan-jaringan yang dapat meningkatkan efisiensi dalam masyarakat melalui fasilitas bagi tindakantindakan yang terkoordinasi. Elemen pokok modal sosial meliputi: (1) saling percaya, (2) kejujuran, (3) pranata yang meliputi nilai-nilai yang dimiliki bersama, norma-norma dan sanksi-sanksi. Elemen-elemen tersebut dalam dinamikanya harus dikreasikan dan ditramsmisikan melalui mekanismemekanisme social budaya di dalam sebuah 
unit sosial seperti keluarga, komunitas, asosiasi sukarela, negara dan sebagainya. Hal-hal tersebut juga akan terwadahi dalam beberapa modal sosial yang bersifat horizontal, seperti paguyuban, asosiasi, organisasi lokal, jaringan sosial, dan dilandasi dengan norma dan nilai yang mengacu pada solidaritas, toleransi, kepercayaan, dan kerja sama.(Eko, 2004, lihat pula Fukuyama,2005; Hasbullah,2006; Hermawanti, dan Hesti Rinandari, 2003; Redaksi Bisnis Indonesia, 2006).

Fukuyama menyatakan bahwa modal sosial merupakan seperangkat nilai atau norma informal yang dimiliki bersama oleh anggota suatu kelompok yang memungkinkan kerja sama di antara mereka (2005; Rahardjo, 2002; Hermawanti dan Rinandari, 2003). Konsep-konsep tersebut menunjukkan pengakuan peran penting organisasi-organisasi informal, nilai-nilai budaya, dan keyakinan agama masyarakat setempat. Modal sosial sangat penting untuk mewujudkan integrasi, kemakmuran dan kesejahtraan suatu masyarakat. Setiap modal sosial akan selalu terkandung adanya dua dimensi yang saling terkait yaitu dimensi kognetif/kultural yang berkaitan dengan nilai-nilai, sikap dan keyakinan yang memengaruhi kepercayaan, solidaritas, dan resiprositas yang mendorong ke arah terciptanya kerja sama dalam masyarakat guna mencapai tujuan bersama. Dimensi kedua adalah dimensi struktural yang berupa susunan ruang lingkup organisasi dan lembaga-lembaga masyarakat pada tingkat lokal, yang mewadahi dan mendorong terjadinya kegiatan-kegiatan kolektif yang bermanfaat bagi seluruh warga masyarakat. (Syahra, 2003). Kedua dimensi ini dalam masyarakat selalu berdinamika. Dinamika dari kedua dimensi ini akan memungkinkan terjadinya keharmonisan, dan juga dominasi, hegemoni, jaringan kuasa.

Dalam konteks inilah tampaknya teori sosial kritis sangat besar manfaatnya, terutama sekali dalam membedahnya. Di dalam modal sosial tercakup berbagai komponen seperti kelompok, identitas kolektif, norma, nilai, kepercayaan, reciprocity, partisipasi, proaktif, tujuan bersama, kerja sama kelompok. Semua itu nantinya akan memengaruhi dinamika jaringan sosial baik dalam konteks tipologi jaringan, struktur jaringan (relasi kekuasaan, rentang dan besaran, orientasi hubungan, dll; spektrum transaksi jaringan dan kualitas jaringan.

Berdasarkan hal tersebut di atas dapat dirumuskan permasalahan sebagai berikut. 1. Bagaimana pola pemukiman masyarakat multietnik pada desa pakraman di Bali?

2. Bagaimana jaringan hubungan sosial masyarakat antaretnik pada desa pakraman di Bali?

3.Bagaimana bentuk-bentuk integrasi antaretnik pada desa pakraman di Bali?

4. Bagaimana model kontrol sosial yang dikembangkan pada desa pakraman dalam pemertahanan modal sosial dan integrasi antaretnik desa pakraman di Bali?

\section{METODE}

Penelitian ini dilakukan di tiga lokasi masyarakat desa pakraman, yaitu Desa Pakraman Buleleng, Desa Pakraman Gelgel, Desa Pakraman Buda Keling. Dalam pengkajian penelitian ini, digunakan pendekatan kualitatif. Adapun informan penelitian ini ditentukan secara purposive snowball. Pengumpulan data dilakukan dengan wawancara, observasi, dan studi pustaka. Data yang terkumpul selanjutnya dianalisis dengan teknik triangulasi data dan disajikan secara deskreptif kualitatif.

\section{HASIL DAN PEMBAHASAN}

Desa pakraman di Bali merupakan satu kesatuan sosial religius. Desa pakraman dipimpin oleh kelian desa pakraman. Dalam melaksanakan tugasnya, dibantu oleh beberapa pembantu seperti: petajuh, penyarikan, petengen, kasinoman, dan kelian banjar. Di samping itu, dalam desa pakraman juga ada pengayom, pamaridabdab, kerta desa, panuriksa, dan 
pecalang. Setiap desa pakraman memiliki wewidangan/ pelemahan, pawongan, dan parahyangan. Keberadaan desa pakraman sebagai satu kesatuan sosial religius sangat penting artinya bagi masyarakat di Bali, baik dalam kaitannya dengan pengembangan jaringan sosial, pembinaan dan pengerahan sumber daya manusia dalam rangka pembangunan sarana dan prasarana dan dalam aktivitas keagamaan yang terkait dengan pelaksanaan Panca Yadnya.

Di samping itu desa pakraman juga sangat berperanan dalam kontrol sosial/pengendalian sosial. Sistem pengendalian sosial oleh Soekanto (1988: 47; Kratz, 1974:74), dinyatakan sebagai suatu proses baik yang direncakan atau tidak direncanakan, yang bertujuan untuk mengajar, membimbing, atau bahkan memaksa warga masyarakat, agar mematuhi nilai-nilai dan norma-norma yang berlaku dalam masyarakat. Sarana pengendalian sosial yang diterapkan oleh organisasi, menurut Etzioni (1985:84) dapat diklasifikasikan ke dalam tiga kategori analitik, yaitu: fisik, material, atau simbolik. Untuk memantapkan proses pengendalian sosial mereka juga mengembangkan berbagai aturan normatif sebagaimana tertuang dalam setiap awig-awig desa pakraman di Bali.

Untuk memantapkan proses pengendalian social, masyarakat terus mengupayakan proses sosialisasi berbagai mekanisme pengendalian sosial dan kontruksi sosial. Hal itu dilakukan melalui berbagai kelembagaan baik formal maupun informal. Dalam konteks inilah berbagai ruang publik menjadi arena bagi proses kontruksi sosial. Dalam proses pengendalian social, masyarakat memiliki berbagai kelembagaan informal seperti keluarga, Ikuren, dadia, banjar, seka, desa pakraman, dan pasraman. Di samping itu, juga ada kelembagaan formal seperti berbagai kelembagaan pendidikan, dan desa dinas. Proses ini oleh Foucault dikenal dengan pendisiplinan (1997). Proses pengendalian sosial masyarakat Bali juga menggunakan berbagai teknologi baik yang bersifat tradisional maupun yang modern, seperti: kulkul, surat, telpon, radio, pengeras suara (Foucault, 1997; Hardiman, 1990). Secara umum, dapat dinyatakan bahwa masyarakat Bali mengembangkan sistem pengendalian sosial yang bersifat sekala dan niskala. Proses pengendalian sosial dalam masyarakat Bali bisa berasal dari bawah dan dari atas (Keesing, 1992; Scott, 1993).

Dari perspektif sosiokultural masyarakat Desa Pakraman Buleleng, Desa Pakraman Gelgel, Desa Pakraman Buda Keling, Desa Pakraman Dalung bersifat multikultur. Kemultikulturannya dapat dilihat dari adanya berbagai etnik yang ada di daerah tersebut. Di Desa Pakraman Buleleng tinggal etnis Tionghoa, Arab, Sasak, Madura, Padang, Bugis, Timor, dan lain sebagainya. Di Desa Pakraman Buda Keling tinggal etnik Bali, dan etnik Sasak. Di Desa Pakraman Gelgel tinggal etnik Bali, etnik Jawa, dan Madura. Di Desa Pakraman Dalung tinggal etnik Bali, Jawa, Madura, Tionghoa, dan Padang. Keberadaan kemultietnikan dan kemultikulturan dari masyarakat desa pakraman di Bali terpresentasikan juga dari adanya perkampungan yang berlatar belakang etnik, seperti Banjar Bali, Banjar Jawa, Kampung Bugis, Kampung Muslim, Kampung Sasak, Kampung Arab. Adanya perkampungan semacam ini dilatar belakangi oleh proses migrasi dan pemertahanan identitas etnik yang ada serta pengembangan rasa aman di daerah rantau yang multietnik. Pengembangan dan pertahanan identitas etnik juga dipresentasikan dengan munculnya berbagai kelompok yang berlatar belakang etnik, seperti Kelompok Suka Duka Keluarga Besar Masyarakat Sasak, Kelompok Suka Duka Keluarga Besar Masyarakat Bugis, Kelompok Suka Duka Masyarakat Cina, Kelompok Suka Duka Masyarakat Sumba, Kelompok Suka Duka Masyarakat Padang, dan sebagainya. Bahkan di kalangan mahasiswapun hal seperti itu juga berkembang, ini dapat dilihat dari 
munculnya kelompok mahasiswa yang berlatar belakang kedaerahan, seperti Kelompok Mahasiswa Lombok. Kemulti etnikannya masyarakat juga tampak dari adanya sarana publik seperti pemakaman Cina/Kuburan Cina.

Kemultikulturan suatu masyarakat juga dapat dilihat dari adanya berbagai kelompok keagamaan. Di desa pakraman di Bali ada berbagai kelompok keagamaan seperti: Hindu, Islam, Katolik, Protestan, Budha, dan Kong Hu-Tsu. Keberadaan masing-masing kelompok keagamaan tersebut memiliki tempat ibadah, seperti pura bagi umat Hindu, masjid bagi umat Islam, gereja bagi umat Kristen dan Protestan, wihara bagi umat Budha. Identitas kemultikulturan juga dapat dilihat dari adanya kelembagaan-kelembagaan yang berbasis keagamaan, seperti PHDI bagi umat Hindu, kelompok pengajian bagi umat Islam, tempat pembinaan umat bagi Kristen dan Protestan. Presentasi kemultikulturan juga dapat disimak dari adanya ruang publik yang berlatar belakang etnik, seperti kuburan (Kuburan Kristen, Kuburan Cina, Kuburan Muslim, Kuburan Hindu), pendidikan (PGA, STKIP Agama Hindu, Muhamadiyah, SMU Swastiastu/Kristen, Kursus Bahasa Mandarin, Kursus Bahasa Arab, dan lainlain). Presentasi dari kemultietnikan/ kemultikulturan masyarakat desa pakraman di Bali juga dapat dilihat dari adanya pelayanan publik yang berbasis etnik/ikatan primordial seperti warung muslim, Budha haha, Bakso Bali, Rumah Makan Padang, Bakso Solo, Warung Sate Madura, Warung Jawa, dan lain-lain. Kemultikulturan juga dapat dilihat dari pakaian yang dipergunakan dan aktivitas-aktivitas sosial yang berbasis ikatan primordial, seperti bahasa pergaulan, nama panggilan dalam pergaulan, dan lain-lain. Kondisi kemajemukakan masyarakat desa pakraman akan semakin bervariasi bila dilihat secara vertikal maupun secara horizontal (Nasikun, 1987). Secara horizontal, masyarakat desa tidak hanya menampakkan adanya variasi etnik, tetapi juga varisasi agama, klan/wangsa, orientasi politik, pekerjaan, sedangkan secara vertikal akan menampakan berbagai variasi jenjang kehidupan dalam berbagai dimensinya, baik dari dimensi ekonomi, pendidikan, dan kekuasaan. Masing-masing kelompok tersebut tentu saja akan menampilkan pola budaya, identitas, jaringan sosial, dan perilaku sosial yang berbeda antara satu kelompok/ lapisan dengan kelompok/lapisan yang lain. Dalam kontek rwa bhinenda atau oposisi binary, kondisi kemultietnikan/kemultikulturan masyarakat desa pakraman di Bali di satu pihak menjadi kebanggaan, merupakan modal sosial/budaya, tetapi di sisi yang lain juga merupakan sumber kerawanan dan konflik. Sehubungan dengan hal itulah, diperlukan upaya penggalian sumber-suber pengintegrasi masyarakat baik melalui pengungkapan pengakuan akan kebinnekaan maupun keikaan/ pluralisme dan universalisme. Hal itu lebih jauh akan memberikan kontribusi yang positif bagi berkembangnya dialog, toleransi, dan integrasi.

Keberadaan masyarakat multietnik tentu juga nampak dari adanya masyarakat yang tinggal/bermukim di desa pakraman di Bali. Pola pemukiman masyarakat multietnik umumnya memusat dalam satu kesatuan etnik dan cenderung bermukim di sekitar pusat-pusat aktivitas ekonomi, seperti pusat pertokoan, pelabuhan, pasar dan dijalanjalan utama. Hal seperti ini nampak juga pada pola pemukiman masyarakat multietnik di Desa Pakraman Buleleng, Gelgel, Dalung,dan Buda Keling. Mereka umumnya tinggal di pusat-pusat aktivitas ekonomi, yang berdekatan dengan aktivitas pasar dan cenderung berbaur dengan pemukiman masyarakat setempat. Kenyataan itu memungkinkan terjadinya hubungan sosial yang semakin intensif dan bahkan ada yang sampai dalam bentuk perkawinan antaretnis. $\mathrm{Hal}$ ini diperkuat dengan berbagai ritual sosial tegur sapa atau tolong menolong pada berbagai kegiatan suka duka. Kondisi 
semacam itu memungkinkan terjadinya pengembangan modal sosial baik dalam bentuk hubungan pertetanggaan, suka duka, gotong royong, maupun dalam bentuk jaringan sosial lainnya. Pola pemukiman sebagai arena sosial sebagaimana dikonsepsikan oleh Pierre Bourdieu (Rindawati,2010) pada desa pakraman dapat menjadi ruang bagi proses dialog sebagai bagian dari tindakan komunikatif yang dikembangkan oleh Jurgen Habermas (Habermas, 2006) dan ruang konstruksi sosial meminjam konsepsi peter $L$ Berger dan Thomas Lukman (Sriningsih, 2010) dalam penguatan modal sosial dan integrasi.

Dalam masyarakat multikultural di desa pakraman di Bali, hubungan sosial pada umumnya mempergunakan bahasa Indonesia baik dalam kontek hubungan antara individu dengan individu maupun individu dengan kelompok dan kelompok dengan kelompok. Penggunaan bahasa Indonesia dalam dialog antaranggota masyarakat tentu saja akan dapat mengurangi terjadinya miskonsepsi dan memudahkan adanya kesatuan pemahaman tentang berbagai permasalahan sosial yang dihadapinya. Walaupun kadang-kadang diselingi dengan penggunaan bahasa etnik, seperti bahasa Bali, Jawa, Sasak, Madura, dan Cina. Namun pada desa pakraman di daerah pedesaan seperti di Desa Buda Keling, digunakan bahasa Bali. Pola pemukiman yang dikembangkan oleh masyarakat multietnik pada desa pakraman tidak saja berkontribusi pada kehidupan ekonomi tetapi juga kehidupan sosial/ jaringan sosial/ modal sosial bahkan integrasi sosial bagi masyarakat multietnik dan masyarakat Bali pada umumnya.

Jaringan sosial yang dikembangkan dalam kehidupan di wilayah pemukiman pada awalnya berupa jaringan hubungan sosial yang didasarkan atas kedekatan tempat tinggal. Hal ini dilandasi oleh pemikiran bahwa tetangga merupakan teman yang paling dekat dalam mengatasi masalah suka dan duka. Jaringan hubungan sosial yang juga dikembangkan adalah jaringan hubungan sosial yang di dasarkan atas kekerabatan sebagai akibat adanya proses perkawinan antaretnik di Bali. Jaringan hubungan sosial yang lain adalah yang didasarkan atas identitas etnik. Hal ini dapat dilihat dari adanya perkumpulan suka duka etnis seperti: Suka Duka Tionghoa Ling San Ting/Bukit Suci, Paguyuban Masyarakat Sasak, Masyarakat Jawa, Madura, dan Padang. Di samping itu, ada juga jaringan sosial yang didasarkan atas kepentingan anggota masyarakat seperti dengan pengembangan perkumpulan olah raga, kelompok arisan, kerja sama dalam bidang ekonomi (misalnya dengan membuat kongsi dagang bersama), di bidang politik (misalnya dengan menjadi anggota satu partai politik) atau dengan memasuki kelompok sepiritual. Arena sosial semacam ini sangat penting artinya dalam pengembangan jaringan hubungan sosial. Jaringan hubungan sosial lainnya juga tampak pada arena sosial gerak senam Taichi. Latihan ini diikuti oleh anggota masyarakat dari berbagai etnis, termasuk juga etnis Bali dan etnis Tionghoa. Belakangan ini Cik Ngah pemilik Toko Cipta dan Pak Surya pemilik Maha Surya Motor menjadi sponsor utama dari kegiatan olah raga tenaga dalam Ling Tien Kung. Kegiatan latihan dilakukan di Pabean dan di Rangon Sanset (rumah makan milik etnis Bali). Kegiatan ini juga diikuti oleh berbagai etnis, baik etnis Bali, Tionghoa, dan Jawa. Pengembangan jaringan sosial antaretnis juga dilakukan terhadap tempat-tempat ibadah, seperti dalam setiap piodalan di Pura Segara, Pura Desa, Pura Dalem, dan Pura Jagat Natha, mereka selalu datang ngaturang sembah bakti dan mengaturkan dana punia baik berupa uang maupun barang. Pengembangan jaringan sosial juga dilakukan melalui aktivitas yang ditekuni, seperti yang dilakukan oleh Cik Ha Myo dan Jro Era yang sama-sama menekuni perdukunan/tukang pijat. Mereka mengembangan hubungan sosial melalui layanan jasa perdukunan/pemijatan. 
Kondusifnya masyarakat multikultur juga dapat dilihat dari adanya kerja sama antaretnik dalam berbagai ruang publik, seperti misalnya di Pasar Anyar I/II. Pasar Buleleng, di Pasar Banyuasri. Dan di Pasar Pupuan. Dalam aktivitas pasar, mereka menampakkan hubungan yang harmonis. Hal ini tampak dari adanya kesediaan dari pedagang kelompok etnik tertentu kepada kelompok etnik lainnya memberikan peminjaman tempat, alat, barang, dan bahkan uang, di samping bantuan tenaga. Presentasi kemultikulturan juga dapat disimak dari barang yang dijualnya, seperti pedagang kembang/canang, be guling, siobak, alat dan perlengkapan upacara (etnik Bali/Hindu), Busana Muslim (Muslim), dan sate kambing (Madura). Hal ini semakin luas ruangnya bila dikaitkan dengan adanya berbagai organisasi/kelompok lintas etnik. Dalam berbagai aktivitas ritual baik yang dilakukan oleh masyarakat Hindu maupun non-Hindu selalu diupayakan adanya kerja sama antara yang satu dengan yang lainnya.

Mantapnya hubungan tersebut juga diperkuat oleh adanya layanan-layanan publik yang terbuka bagi berbagai macam etnik/subkultur, seperti yang dilakukan oleh tukang pijat di Kampung Anyar (Muslim), Banyuasri (Muslim dan Kristen), dan Delod Peken (Hindu), sebagaimana yang dilakukan oleh Cik A Mio (Cina/Budhis), atau sebagaimana yang dilakukan oleh almarhum Pak Ketut Wijana (Pak Item). Mereka ini memberikan pelayanan dengan keterbukaan, ketulusan, dan penuh kasih. Monumen kemantapan hubungan antaretnik/sub kultur juga dapat dilihat dari adanya keterbukaan kelembagaan umat untuk saling mengakui, saling menyadari, dan saling menerima. Hal ini dapat dilihat dari keterbukaan Pura Taman Sari bagi setiap umat beragama pura ini terbangun dari sumbangan berbagai umat baik yang beragama Hindu, Budha, Kristen, Muslim dan Kong Hu-Tsu. Keterbukaan semacam ini juga tampak pada Klenteng di Pabean. Tempat ini dijadikan simpul hubungan antar umat beragama, karena tempat suci ini terbuka bagi masyarakat umum untuk berkunjung, menanyakan nasib, keberuntungan, dan obat. Di samping itu, di tempat ini juga sering dilakukan latihan barong sai, yang terbuka untuk umum.

Dalam masyarakat desa pakraman di Bali sebagaimana telah dikemukakan di atas telah dikembangkan berbagai kearifan sosial yang dapat menjadi perekat sosial dalam masyarakat multikultural. Dalam tataran teks kognitif dalam masyarakat, terdapat ungkapan kearifan sosial seperti celebingkah batan biu, gumi linggah ajak liu (Bumi ini luas dan ditempati banyak orang), don sente don pelendo, ade kene ade keto (ada yang begini ada yang begitu/ penghargaan terhadap variasi sosial). Teks yang lain yang tak kalah pentingnya adalah ungkapan buka nyuhe aijeng (seperti kelapa satu tangkai tidak ada yang sama). Hal itu lebih lanjut diperkuat dengan aturan awigawig desa yang menyatakan bahwa krama desa terdiri dari krama negak dan krama tamiu (krama yang duduk sebagai anggota desa pakraman, dan krama yang diposisikan sebagai pendatang). Teks kognitif yang lain adalah adanya ungkapan nyama Madura, nyama Jawa, nyama Sasak, nyama Arab, dan nyama Cina. Ungkapan menyama artinya bersaudara. Ungkapan-ungkapan semacam itu juga berkembang pada masyarakat etnik Tionghoa, bahkan ada ungkapan yang menyatakan bahwa etnik Tionghoa merupakan kakak dari etnik Bali. Pernyataan kakak dan adik dalam hubungan antaretnik menyiratkan akan adanya hubungan persaudaraan/geneologis. Ungkapan tersebut tidak saja mengakui, tetapi juga menguatkan pandangan bahwa siapapun yang tinggal di wilayah desanya adalah saudaranya yang harus diakui, diterima, dan dihormati. Di samping teks kognitif juga dalam masyarakat berkembang teks sosial seperti misalnya adanya kehidupan kelompok suka duka lintas sub kultur, adanya kelembagaan ngopin (membantu), medelokan (berkunjung), dan adanya kelembagaan makanan penyelam 
(masakan yang tidak menggunakan daging babi). Teks sosial yang lainnya misalnya dalam bentuk kerja sama antarumat beragama, misalnya pada saat Upacara Tawur Kesanga dan Nyepi umat Hindu memohon bantuan dari umat non-Hindu lainnya untuk membantu. Demikian pula pada saat umat lainnya melakukan aktivitas sosial keagamaan. Hal semacam itu merupakan modal budaya dan modal sosial yang sangat penting artinya dalam memanajemen masyarakat multi kultur.

Pengembangan jaringan hubungan sosial yang dilakukan oleh berbagai etnis dalam masyarakat multietnis akan menentukan munculnya berbagai bentuk integrasi antaretnis. Dalam masyarakat desa pakraman dimungkinkkan adanya integrasi antaretnis di Bali. Hal ini terkait dengan adanya kedudukan anggota desa pakraman sebagai kerama sampingan dan krama tamiyu. Hal seperti itu juga dikembangkan oleh desa pakraman di Bali. Dalam kapasitasnya sebagai krama tamiyu lan krma sampingan anggota etnis non-Bali dikenai dana punia penyepian dan dana punia lainnya sesuai pararem. Bentuk integrasi antaraetnis dengan etnis Bali adalah dalam bentuk perkawinan/satu ikatan keluarga. Bentuk integrasi perkawinan/ keluarga intensitas integrasinya tidak saja mencakup integrasi antara suami dan istri, tetapi meluas dalam bentuk integrasi antar kerabat suami dan kerabat istri, seperti yang dialami oleh Dewa Aji Mangku Suwija (55), Sukasna Pandit (40), Pun Bun Siok (58), Tiong Kok Yen (62), turut membantu aktivitas upacara yang diselenggarakan. Hal seperti itu juga terjadi di desa lainnya di Bali. Hal itu dibenarkan oleh I Nengah Bumbung, seperti misalnya perkawinan Nengah Wirya Kusuma (60) denga Dina Wati (55), I Gusti Putu Eka (50) menikah dengan Roosmini (40). Mereka merasakan jaringan sosial mereka semakin luas melalui perkawinan antaretnis. Hal ini tentu saja memperkuat integrasi mereka dengan etnis lainnya. Bentuk integrasi yang lainnya adalah dalam bentuk ikatan persekutuan/organisasi/ perkumpulan antaretnis baik dalam kaitannya dengan aktivitas sosial seperti Suka Duka Adnyana Suci. Perkumpulan Olah Raga Taichi, Ling Tien Kung, Tinju, Tenis. Dalam bidang ekonomi seperti Kongsi Dagang. Dalam bidang budaya Perkumpulan Barong Sai, maupun masuk pada partai politik tertentu. Simpul-simpul sosial seperti itu sangat berkontribusi dalam penguatan integrasi sosial lintas etnis dalam masyarakat multikultur. Penguatan integrasi antaretnis Bali dengan etnis Tionghoa juga dikontribusi oleh adanya mitos hubungan geneologis dan kultural. Hal itu misalnya dapat disimak dari ceritra hubungan antara etnis Bali dengan etnis Tionghoa bagaikan hubungan dua saudara sekandung, kakak ber adik.

Pengendalian sosial pada dasarnya menghubungkan penyimpangan dengan lemahnya ikatan terhadap lembaga-lembaga dasar masyarakat, keluarga, agama, sekolah dan peradilan. Kratz (1974: 74) menyatakan bahwa pengendalian sosial pada dasarnya merupakan suatu cara dengan mana suatu kelompok, golongan atau lapisan masyarakat tertentu melaksanakan keseimbangan atau mengubah struktur nilai-nilai politik, kebudayaan, agama dan adat sopan santun. Sehubungan dengan hal itu, bagi masyarakat Bali yang beragama Hindu tujuan yang membimbing dan mengarahkan perilakunya adalah nilai-nilai yang tertuang dalam ajaran agama Hindu, seperti: Tat Twam Asi, Tri Kaya Parisudha, Karma Pala, Yajna, Guru Bhakti, dan lain sebagainya. Hal-hal seperti itu juga dijadikan dasar dalam proses pengendalian sosial pada masyarakat desa pakraman di Bali, untuk menjaga modal sosial dan integrasui antaretnik. Tat Twam Asi merupakan cermin cinta kasih yang universal antara sesama. Tat Twam Asi yang berarti dia adalah engkau mencakup pengertian menyakiti orang lain berarti menyakiti diri sendiri, menolong orang lain berarti juga menolong diri sendiri. Jadi, nampak adanya solidaritas sosial yang tinggi. Tat Twam Asi adalah rasa 
toleransi yang menimbulkan rasa persaudaraan dan kerukunan hidup antarsesama manusia yang mewarnai tata susila Hindu, seperti rasa tresna asih, anresangsia, catur paramita, tri kaya pariudha, dan yadnya. Sikap-sikap semacam ini tentu akan dapat mengendalikan perilaku social anggota masyarakat Bali, lebih-lebih dengan adanya ideologi trikaya parisudha dan karma phala sehingga tidak terjadi perlakuan-perlakuan yang kurang terpuji terhadap orang lain. Pengendalian sikap dan prilaku yang kurang terpuji dan pengembangan sikap welas asih dan tresna bhakti akan dapat menjadi kekuatan bagi kerukunan antarsesama umat manusia. Pemahaman individu atau anggota masyarakat terhadap nilai-nilai spiritual dan adat istiadat setempat akan memengaruhi pola perilakunya kehidupannya dalam berbagai sistem sosial seperti keluarga, dadia, banjar, desa adat/dinas dan kelembagaan lainnya.

Dalam masyarakat desa pakraman di Bali, sistem sosial terkecil adalah keluarga inti atau di Bali. Hal itu disebut dengan istilah kuren. Kuren memainkan peranan yang penting dalam proses pengendalian sosial. Di dalam kuren inilah mulai disosialisasikan tentang nilai-nilai adiluhung yang harus direfleksikan oleh setiap anggota keluarga dalam perilakunya di masyarakat. Sistem sosial yang lebih besar dari keluarga adalah dadia. Dadia pada masyarakat Bali pada dasarnya merupakan kumpulan beberapa kuren/ keluarga inti dari garis keturunan kepurusa (garis keturunan dari pihak laki-laki). Masyarakat Bali di samping terikat dalam kesatuan keluarga dan dadia juga terikat dalam kesatuan tempat tinggal bersama, kesatuan administrasi dan seka (Geertz, 1979). Dinamika sistem sosial budaya Bali mengacu pada konsepsi desa, kala, patra dan dharma, artha, kama.

Dalam dinamika sistem

pengendalian sosial, masyarakat Bali menggunakan berbagai teknologi, baik teknologi tradisional maupun teknologi modern (Foucault, 1997). Pandangan semacam ini sejalan dengan perspektif materialis, yang memandang bahwa teknologi memberikan sumbangan yang besar bukan saja dalam proses produksi, tetapi juga dalam proses perubahan sosial budaya dan sekaligus kontrol sosial (Suseno, 1995). Hal seperti ini juga dilakukan di desa pakramandi Bali yaitu melalui pengeras suara, surat, atau pengumuman lewat RRI Singaraja. Di samping itu dalam masyarakat juga berkembang bahasa sebagai sistem pengendalian sosial, karena tanpa adanya bahasa komunikasi secara sosial tidak mungkin berlangsung. Hal ini dapat disimak dari adanya kebiasaan menggunakan sindiran, ungkapan-ungkapan (sesenggakan, wangsalan, bladbadan) seperti : Yen ngae baju sikutang di deweke (Kalau buat pakaian ukur pada diri sendiri). Artinya kalau berbuat kembalikan pada diri sendiri), gunjingan dan tidak bicara dalam masa waktu tertentu/puik, dalam proses pengendalian sosial. Dengan demikian secara singkat dapat dikatakan masyarakat desa pakraman di Bali dalam proses kontrol sosial/pengendalian sosial untuk mempertahankan modal sosial dan integrasi antaretnik menggunakan pendekatan sekala dan niskala.

\section{SIMPULAN}

Berdasarkan uraian tersebut di atas maka dapat disimpulkan sebagai berikut:

1. Desa pakraman di Bali merupakan masyarakat multietnis; kemultietnikan tersebut dapat dilihat dari adanya berbagai kelompok etnik yang bermukim di wilayah tersebut, seperti etnis Bali, etnis Tionghoa, etnis Jawa, etnis Madura, etnis Sasak, dan lain-lain.

2. Pola pemukiman masyarakat multietnis pada umumnya memusat dan cenderung di pusat aktivitas ekonomi, jalur utama dan cenderung berbaur dengan etnis lainnya.

3. Jaringan hubungan sosial yang dikembangkan ada yang didasarkan atas kedekatan tempat tinggal, kekerabatan, 
kepentingan sosial, ekonomi, budaya dan politik.

4. Bentuk integrasi sosialnya dalam bentuk perkawinan, hubungan pertetanggaan, hubungan tempat tinggal, persekutuan/perkumpulan/organisasi sosial baik yang berbasis sosial, budaya, ekonomi maupun politik.

5. Model kontrol sosial yang dikembangkan berupa penanaman nilai melalui sosialisasi, pemanfaatan sisitem sosial keluarga/kuren, desa pakraman, kelembagaan formal lainnya, dan dengan pemanfaatan budaya fisik seperti surat, telpon, radio, pengeras suara. Di samping itu juga dengan menggunakan bahasa. Dengan kata lain kontrol sosila dalam pemeliharaan modal sosial dan integrasi antar etnik dilakukan secara sekala dan niskala.

\section{Saran-saran}

1. Kondisi kemultietnikan masyarakat memerlukan kebijaksanaan pemerintah secara optimal dalam pemeliharaan kondisi yang kondusif sehingga menjadi kekuatan positif dalam berbagai dinamika kehidupan masyarakatnya.

2. Pola pemukiman yang berbaur sangat rentan bagi terjadinya konflik. Untuk itu upaya pengembangan keterbukaan/ dialog yang adil dan berkesinambungan perlu terus diupayakan.

3. Kesadaran dan partisipasi masyarakat multietnik dalam mengembangankan jaringan sosial perlu terus dikembangkan melalui kebijakan pemerintah dan sosialisasi pada masyarakat .

4. Berbagai bentuk integrasi antar etnik Bali dengan etnik lainnya perlu terus dikembangkan baik melalui kebijakan pemerintah, maupun melalui penelitian dan pengabdian masyarakat dari kelembagaan perguruan tinggi

4 Berbagai model kontrol sosial dalam mempertahankan modal sosial dan integrasi antaetnik dapat dijadikan sebagai suatu inspirasi dalam mengatasi permasalahan yang berkembang pada masyarakat multietnik.

\section{DAFTAR PUSTAKA}

Adicondro, G.Y, 1978 "Dari Pecinan sampai Nanyang Suatu Introduksi tentang Kewirausahaan Orang Cinan di Indonesia" dalam Prisma, Oktober No.9 Jakarta: LP3ES.

Agung,Ide Anak Agung Gde, 1989. Bali Pada Abad XIX, Yogyakarta: UGM Pres.

Ardika, I Wayan, 1989. " Bali dalam Sentuhan Budaya Global Pada Awal Abad masehi" dalam Dinamika Kebudayaan Bali. I Wayan Ardika dan I Made Sutaba (ed). Denpasar: Upanisad.

Atmadja, Nengah Bawa, 1997. Pendidikan Manusia Antarbudaya, Bali Post 11 April 1997.

Atmadja, Nengah Bawa, 2006, Bali Pada Era Globalisasi, Singaraja: IKIP N Singaraja

Badaruddin, 2005, Modal Sosial (Sosial Capital) dan Pemberdayaan Komunitas Nelayan, dalam Isu-isu Kelautan Dari Kemiskinan Hingga Bajak Laut, Yogyakarta: Pustaka Pelajar.

Bagus, I G Ngurah, 1975. "Kebudayaan Bali" dalam Manusia dan Kebudayaan. Koentjaraningrat (ed). Jakarta: Djambatan.

Burhanuddin, 1988. "Ace dan Baba, dalam Stereotip Etnik, Asimilasi, Integrasi Sosial, Jakarta: Grafika Kita.

Coppel, Charles A, 1994. Tionghoa Indonesia Dalam Krisis. Jakarta: Pustaka Sinar Harapan.

Coleman, James S. 2011. Dasar-Dasar Teori Sosial. Bandung: Nusamedia

Eko, Sutoro, 2004, Modal Sosial, Desentralisasi dan Demokrasi Lokal, dalam Jurnal Analisis CSIS, Vol.33,No.3, Sept 2004, Jakarta:

Jurnal IImu Sosial dan Humaniora | 219 
CSIS Foucault, Michel, 1997, Disiplin Tubuh, Bengkel Individu Moder, Yogyakarta: LKiS.

From, Erich, 1996. Revolusi dan Harapan, Yogyakarta: Pustaka Pelajar.

Fukuyama, Francis. 2005. Guncangan Besar. Jakarta: Gramedia

Galtung,J, 1988. "Kekerasan dan Penelitian Perdamaian", dalam M Lubis (ed) Menggapai Dunia Damai, Jakarta: YOI.

Geertz,C, 1979. Penjaja dan Raja, Perubahan Sosial di Dua Kota Indonesia. Jakarta: Gramedia.

Geertz,C, 2000. Negara Teater. Yogyakarta: Bentang Griya, Nyoman, 1995. Amalgamasi Etnik Tionghoa di Singaraja, Skrepsi (S1). FKIP-UNUD: Denpasar.

Hardiman, Francisco, 1990. Kritik Ideologi Pertautan pengetahuan dan Kepentingan, Yogyakarta: Kanisius

Hasbullah, Jousairi,2006, Sosial Capital, Menuju Keunggulan Budaya Manusia Indonesia,

Jakarta: MR-United Press.

Hendarti, Paulina Ratna, 1975. Perbedaan Orientasi Nilai Budaya Antara Generasi Muda dan Orang Tua Golongan Keturunan Cina. Jakarta: Leknas.

Hermawanti dan Hesti Rinandari, 2002, Penguatan dan Pengembangan Modal Sosial Masyarakat Ada, dalam Copyright @ 2003 Institute For Research and Empowerment.

Kartodirdjo, Sartono, 1975. Sejarah nasional,Jakarta: Depdikbud.

Koentjaraningrat, 1981. Pengantar Antropologi, Jakarta: Aksara Baru.
Koentjaraningrat, 1982, Masalah-Masalah pembangunan Bunga Rapai Antropologi Terapan.

Jakarta: LP3ES.

Kratz, Ulrich, 1974. Bahasa, Komunikasi, dan Kontrol Sosial, dalam Prisma 6/1974.Jakarta: LP3ES

Mohamad, Goenawan, 1998. Pemerkosaan Masal, dalam Tempo l/10/1998.

Mohamad, Kartono, 1998. Reine, dalam Tempo l/10/1998.

Mudana, I Wayan,.2000. Integrasi Etnik Tionghoa Pada Masyarakat Desa Adat di bali Kasus Catur-KintamaniBali. Singaraja: STKIP.

Muliana, Slamet, 1981. Kuntala Sriwijaya dan Swarna Bumi. Jakarta: Indayu.

Onghokham, 1983. Rakyat dan Negara. Jakarta: Sinar Harapan

Onghokham, 1991. Minoritas Cina dan Globalisasi., dalam Tempo No.26/8/1991.

Pageh, Made, 1998. Peranan Syahbandar Cina di pantai Utara Bali Pertengahan Abad XIX dan Awal Abad XX, Makalah S2 Sejarah. Yogyakarta: UGM Press

Prime, Ranchore, 2006, Tri Hita Karana Ekologi Ajaran Hindu, Surabaya: Paramita

Siahaan, Harlem, 1994. "Konflik dan Perlawanan Kongsi Cina di Kalbar" dalam Prisma 12/1994. Jakarta: LP3ES.

Sinergi, 2001. Edisi ke 30/15- Maret 2001. Jakarta: Yayasan Media Maitri.

Simmel, Gerhard F., 1986. Berdagang dengan Cina. Jakarta: Pustaka Azet.

Soekanto dan Tjandrasari, 1987. J.S. Roucek Pengendalian Sosial.Jakarta: Rajawali.

Jurnal IImu Sosial dan Humaniora | 220 
Tabloid Altenatif Bongkar, 1998

Tempo, Edisi 6-12 Okt 1998.

Tilar, H.A.R, 2000, Pendidikan Kebudayaan dan Masyarakat Madani Indonesia, Bandung: Rosdakarya

Tim Pencari Fakta, 1998, Puncak Kebiadaban Bangsa Pemerkosa Etnik Tionghoa. Jakarta: Matra.

Vasanty, Puspa, 1987. " Kebudayaan Orang Tionghoa Indonesia", dalam Manusia dan Kebudayaan di Indonesia. Koentjaraningrat (ed). Jakarta: Djambatan.

Werdoyo, T.S. 1990. Tan Jui Sing.

Wickberg, Edgar, 1991. "Perkumpulan dan Etnisitas Orang Cina Asia Tenggara dan Amerika Utara", dalam Perubahan Identitas Orang Cina di Asia Tenggara. J. Cushman dan Wang Gungwu (ed). Jakarta: Grafiti.
Widiarsono, 1993, Teknologi dan Sains, Sebagai Ideologi, dalam Diskursus Kemasyarakatan dan Kemanusiaan, Jakarta: Gramedia.

Wiana, Ketut, 2006, Menyayangi Alam mewujudkan Bhakti Kepada Tuhan, Surabaya: Paramita

Wong, John, 1987. Politik Perdagangan Cina di Asia Tenggara. Jakarta: Bumi Aksara. Yayasan Tunas Bangsa, 1989. Lahirnya Konsepsi Asimilasi. Jakarta: YTB

Yusuf, Yumar, 1998. "Relasi Baba Tauke dan Awang Melayu", dalam Prisma 12/1994.

Jakarta: LP3ES.

Zen, M.T., 1988. Sains, Teknologi dan Hari Depan Manusia.Jakarta: Gramedia. 